\title{
Pengaruh jumlah kendaraan bermotor, jumlah penduduk dan kebijakan pemerintah terhadap pertumbuhan ekonomi melalui penerimaan pajak kendaraan bermotor (PKB) di Provinsi Jambi
}

\author{
Hadi Tiawan*; Erfit ; Zulgani \\ Prodi Ekonomi Pembangunan Fak. Ekonomi dan Binsis Universitas Jambi \\ *E-mail korespodensi :haditiawan7@gmail.com
}

\begin{abstract}
This study aims to: (1) To find out and analyze the influence of the number of motorized vehicles, population, and government policy on the acceptance of PKB in Jambi Province in the period 2000-2018, and (2) To find out and analyze the influence of the number of motorized vehicles, population, government policies and PKB's acceptance of economic growth in Jambi Province in the period 2000-2018. This study uses the Path Analysis method. Based on the results of the study that the independent variable that affects motor vehicle tax revenue is the population. The results of the path analysis for structural equation I, namely the contribution of the population in Jambi Province directly have a positive impact on motor vehicle tax revenues in Jambi Province. Furthermore, the independent variables that influence economic growth are the number of vehicles and the population. The results of the path analysis for structural equation II namely the contribution of the number of motorized vehicles in Jambi Province directly have a positive impact and the indirect effect through the population contributes negatively to economic growth in Jambi Province. Furthermore, the contribution of the population in Jambi Province directly has a positive impact and the indirect effect through the number of motor vehicles contributes negatively to economic growth in Jambi Province.
\end{abstract}

Keywords: Motorized vehicles, Population, Government policy, Motorized vehicle tax revenue, Economic growth.

\begin{abstract}
Abstrak
Penelitian ini bertujuan untuk: (1) Untuk mengetahui dan menganalisis pengaruh jumlah kendaraan bermotor, jumlah penduduk dan kebijakan pemerintah terhadap penerimaan PKB di Provinsi Jambi dalam periode 2000-2018, dan (2) Untuk mengetahui dan menganalis pengaruh jumlah kendaraan bermotor, jumlah penduduk, kebijakan pemerintah dan penerimaan PKB terhadap pertumbuhan ekonomi di Provinsi Jambi dalam periode 2000-2018. Penelitian ini menggunakan metode Path Analysis. Berdasarkan hasil penelitian bahwa variabel bebas yang mempengaruhi penerimaan pajak kendaraan bermotor adalah jumlah penduduk. Hasil path analisis untuk persamaan struktural I yaitu kontribusi jumlah penduduk di Provinsi Jambi secara langsung berdampak positif terhadap penerimaan pajak kendaraan bermotor di Provinsi Jambi.Selanjutnya variabel bebas yang mempengaruhi pertumbuhan ekonomi adalah jumlah kendaraan dan jumlah penduduk. Hasil path analisis untuk persamaan struktural II yaitu kontribusi jumlah kendaraan bermotor di Provinsi Jambi secara langsung berdampak positif dan pengaruh tidak langsung melalui jumlah penduduk berkontribusi negatif terhadap pertumbuhan ekonomi di Provinsi Jambi. Selanjutnya kontribusi jumlah penduduk di Provinsi Jambi secara langsung berdampak positif dan pengaruh tidak langsung melalui jumlah kendaraan bermotor berkontribusi negatif terhadap pertumbuhan ekonomi di Provinsi Jambi.
\end{abstract}

Kata kunci: Kendaraan bermotor, Jumlah penduduk, Kebijakan pemerintahan, Penerimaan pajak kendaraan bermotor, Pertumbuhan ekonomi 


\section{PENDAHULUAN}

Menurut Mahmudi (2010), jika dibandingkan dengan sektor bisnis, sumber pendapatan pemerintah daerah relatif terprediksi dan lebih stabil, sebab pendapatan tersebut diatur oleh peraturan perundang-undangan daerah yang bersifat mengikat dan dapat dipaksakan. Sedangkan pada sektor bisnis sangat dipengaruhi oleh pasar yang penuh ketidakpastian sehingga pendapatan pada sektor bisnis bersifat fluktuatif. Untuk meningkatkan akuntabilitas dan keleluasaan dalam pembelanjaan Anggaran Pendapatan dan Belanja Daerah (APBD), sumber-sumber penerimaan daerah yang potensial harus digali secara maksimal di dalam koridor peraturan perundangundangan yang berlaku, termasuk diantaranya adalah pajak daerah dan retribusi daerah yang sudah sejak lama menjadi salah satu unsur PAD yang utama.

Berdasarkan UU nomor 22 tahun 1999 pasal 79 disebutkan bahwa sumber pendapatan asli daerah terdiri dari hasil pajak daerah, retribusi daerah, laba BUMD, dan pendapatan lain-lain yang sah. Pajak daerah adalah peralihan kekayaan dari pihak rakyat kepada kas negara untuk membiayai pengeluaran rutin dan surplusnya digunakan untuk Public Investment. Pajak daerah adalah pungutan daerah menurut peraturan yang ditetapakan sebagai badan hukum publik dalam rangka membiayai rumah tangganya. Dengan kata lain pajak daerah adalah pajak yang wewenang pungutannya ada pada daerah dan pembangunan daerah (Kaho, 2007). Salah satu jenis pajak yang memiliki potensi yang semakin meningkat seiring dengan kemajuan teknologi dan standar kebutuhan sekunder menjadi primer adalah pajak kendaraan bermotor. Provinsi Jambi merupakan salah satu daerah dengan jumlah kendaraan yang mengalami peningkatan secara signfikan setiap tahunnya, besarnya jumlah kendaraan roda dua maupun roda empat akan meningkatkan penerimaan PKB sehingga penerimaan PKB merupakan salah satu pendapatan unggulan Provinsi Jambi. Berikut ini dapat dilihat berapa besar kontribusi penerimaan PKB terhadap PAD Provinsi Jambi yang tersaji pada tabel berikut:

Tabel 1. Kontribusi pajak kendaraan bermotor (PKB) terhadap pendapatan asli daerah (PAD) di Provinsi Jambi

\begin{tabular}{cccc}
\hline Tahun & $\begin{array}{c}\text { Penerimaan pajak kendaraan } \\
\text { bermotor (Rp. Juta) }\end{array}$ & $\begin{array}{c}\text { Pendapatan asli } \\
\text { daerah (Rp. Juta) }\end{array}$ & $\begin{array}{c}\text { Kontribusi } \\
(\boldsymbol{\%})\end{array}$ \\
\hline 2000 & 52.726 & 153.289 & 34,40 \\
2001 & 59.751 & 173.117 & 34,51 \\
2002 & 64.215 & 198.497 & 32,35 \\
2003 & 71.357 & 205.990 & 34,64 \\
2004 & 79.384 & 242.744 & 32,70 \\
2005 & 87.542 & 277.452 & 31,55 \\
2006 & 92.308 & 296.224 & 31,16 \\
2007 & 108.045 & 325.788 & 33,16 \\
2008 & 157.940 & 393.484 & 40,14 \\
2009 & 172.043 & 318.020 & 54,10 \\
2010 & 205.335 & 463.717 & 44,28 \\
2011 & 257.250 & 655.490 & 39,25 \\
2012 & 247.997 & 826.514 & 30,01 \\
2013 & 229.115 & 864.478 & 26,50 \\
2014 & 318.466 & 1.010 .560 & 31,51 \\
2015 & 269.236 & 896.048 & 30,05 \\
2016 & 339.433 & 996.872 & 34,05 \\
2017 & 416.706 & 1.335 .478 & 31,20 \\
2018 & 469.261 & 1.521 .288 & 30,84 \\
\hline
\end{tabular}

Sumber : Badan Keuangan Daerah Provinsi Jambi, 2020 
Berdasarkan Tabel 1 dapat dilihat besaran kontribusi penerimaan pajak kendaraan bermotor terhadap PAD Provinsi Jambi setiap tahunnya mengalami peningkatan. Ratarata kontribusi penerimaan pajak kendaraan bermotor terhadap PAD Provinsi Jambi adalah sebesar 34,55 persen. Kontribusi ini terbilang cukup besar dikarenakan selain pajak kendaraan bermotor, masih ada beberapa lagi sumber pajak dan sumber PAD tingkat Provinsi yang lainnya seperti penerimaan bea balik nama kendaraan bermotor (BBN-KB), penerimaan pajak bahan bakar kendaraan bermotor (PBB-KB), penerimaan pajak kendaraan diatas air (PKDA), penerimaan bea balik nama kendaraan diatas air (BBN-KDA), penerimaan pajak air permukaan dan penerimaan pajak air bawah tanah. Faktor-faktor yang dapat mempengaruhi penerimaan PBB yaitu jumlah kendaran bermotor, jumlah penduduk dan kebijakan pemerintah dalam pemutihan pajak.

Provinsi Jambi merupakan salah satu daerah dengan jumlah kendaraan yang mengalami peningkatan setiap tahunnya. Berdasarkan data yang dihimpun dari Badan Keuangan Derah Provinsi Jambi mulai tahun 2000 jumlah kendaraan roda empat sejumlah 10.286 unit kendaraan, pada tahun 2005 meningkat menjadi sejumlah 37.286 unit, pada tahun 2010 meningkat menjadi sejumlah 88.749 unit. Pada tahun 2018 kembali mengalami peningkatan menjadi sebanyak 212.722 unit kendaraan. Rata-rata peningkatan jumlah unit kendaraan roda empat selama tahun 2000-2018 sebesar 8,12 persen.

Peningkatan jumlah kendaraan di Provinsi Jambi juga terjadi pada jumlah kendaraan roda dua, mulai dari tahun 2000 jumlah kendaraan roda dua di Provinsi Jambi sejumlah 98.274 unit kendaraan dan jumlah tersebut terus meningkat, sehingga pada tahun 2005 jumlah kendaraan roda dua di Provinsi Jambi sebanyak 398.875 unit dan jumlah ini kembali meningkat pada tahun 2010 menjadi sebesar 898.989 unit dan meningkat lagi pada tahun 2018 menjadi sejumlah 1.714 .720 unit kendaraan. Kalau dirata-ratakan setiap tahunnya jumlah kendaraan meningkat setiap tahunnya sebanyak 100 ribuan unit kendaran. Meningkatnya jumlah kendaraan tersebut tentunya akan mempengaruhi realisasi penerimaan PBB Provinsi Jambi. Rata-rata peningkatan jumlah unit kendaraan roda dua selama tahun 2000-2018 sebesar 14,28 persen.

Selain jumlah unit kendaraan bermotor, faktor lain yang diduga mempengaruhi penerimaan PKB Provinsi Jambi adalah jumlah penduduk. Semakin meningkat jumlah penduduk maka semakin besar penerimaan PKB. Berdasarkan data yang dihimpun dari BPS Provinsi Jambi, jumlah penduduk Provinsi Jambi selama tahun 2000-2018 terus mengalami peningkatan. Pada tahun 2000 jumlah penduduk Provinsi Jambi sejumlah 2.421.512 jiwa, meningkat pada tahun 2005 menjadi sejumlah 2.656.906 jiwa, meningkat pada tahun 2010 menjadi sejumlah 3.092.265 dan sampai tahun 2018 juga meningkat menjadi sebanyak 3.570.272 jiwa. Rata-rata peningkatan jumlah penduduk Provinsi jambi sebesar selama tahun 2000-2018 sebesar 1,77 persen.

Selanjutnya faktor-faktor lain yang mempengaruhi penerimaan PKB Provinsi Jambi adalah kebijakan pemerintah dalam pemutihan pajak. Pemutihan pajak bertujuan agar wajib pajak yang selama ini menunggak kendaraannya tidak membayar pajak bisa melaksanakan pembayaran disaat pemutihan, akan tetapi walaupun sudah diadakan pemutihan pajak masih belum efisien karena tidak semua masyarakat khususnya di Provinsi Jambi membayar wajib pajak. Pemutihan dapat dilakukan diseluruh kantor SAMSAT di Provinsi Jambi, melalui program pemutihan ini, wajib pajak tidak dikenakan denda, dengan pemutihan pajak kendaraan bermotor akan meningkatkan penerimaan pajak kendaraan bermotor, selain itu akan meringankan masyarakat dalam melakukan mutasi kendaraan, bea balik nama gratis, dan apabila pajaknya menunggak tidak dikenakan dendanya, melainkan membayar pokoknya saja. Pemutihan pajak di Provinsi 
Jambi tidak terus dilakukan setiap tahunnya. Pemutihan pajak dilakasanakan apabila ada kebijakan dari pemerintah untuk pelaksanaannya.

Berdasarkan data diatas terlihat selama beberapa tahun terakhir realisasi penerimaan PKB di Provinsi Jambi terus mengalami peningkatan. Perkembangan yang terus meningkat ini mencerminkan besarnya potensi yang ada dalam penetapan pemungutan PKB. Realisasi PKB yang terus mengalami peningkatan ini diharapkan dapat meningkatkan pertumbuhan ekonomi setiap tahunnya.

Berdasarkan data yang dihimpun dari BPS Provinsi Jambi, pertumbuhan ekonomi selama tahun 2000 sampai tahun 2018 mengalami pertumbuhan yang cenderung meningkat. Tahun 2000 pertumbuhan ekonomi Provinsi Jambi sebesar 3,24 persen dan meningkat pada tahun 2005 menjadi sebesar 5,57 persen dan tahun 2010 meningkat menjadi sebesar 7,35 persen dan mengalami penurunan pada tahun 2018 menjadi sebesar 4,71 persen. Seharusnya peningkatan penerimaan PKB tahun 2018 dapat mempengaruhi pertumbuhan ekonomi Provinsi Jambi di tahun yang sama.

Melihat dari realisasi penerimaan PKB yang terus meningkat dari tahun ke tahun dan faktor-faktor yang mempengaruhinya, serta pengaruhnya terhadap pertumbuhan ekonomi. Maka penulis tertarik untuk meneliti lebih dalam permasalahan tersebut dan dituangkan kedalam bentuk skripsi yang berjudul "Pengaruh Jumlah Kendaraan Bermotor, Jumlah Penduduk dan Kebijakan Pemerintah Terhadap Pertumbuhan Ekonomi melalui Penerimaan Pajak Kendaraan Bermotor (PKB) di Provinsi Jambi".

\section{METODE}

Metode analisis yang digunakan dalam penelitian ini adalah analisis deskriptif kualitatif dan kuantitatif. Analisis deskriptif kualitatif digunakan untuk mendeskripsikan fenomena-fenomena yang berkaitan dengan permasalahan yang berkaitan dengan masalah yang diteliti. Sedangkan analisis kuantitatif digunakan untuk menganalisis informasi kuantitatif (data yang dapat diukur, diuji, dan diinformasikan dalam bentuk persamaan, tabel dan sebagainya.

Adapun model analisis data dalam penelitian ini merupakan model analisis yang digunakan untuk melihat sejauh mana pengaruh secara langsung dan tidak langsung variabel eksogen terhadap suatu variabel endogen. Untuk menganalisis model analisis digunakan model analisis jalur (path analysis).

Analisis jalur merupakan perluasan dari regresi linier berganda, dan yang memungkinkan analisis model-model yang lebih kompleks" (Streiner, 2005) "Analisis jalur ialah suatu teknik untuk menganalisis hubungan sebab akibat yang tejadi pada regresi berganda jika variabel bebasnya mempengaruhi variabel tergantung tidak hanya secara langsung tetapi juga secara tidak langsung". (Robert D. Retherford 1993). Sedangkan menurut Paul Webley (1997): "Analisis jalur merupakan pengembangan langsung bentuk regresi berganda dengan tujuan untuk memberikan estimasi tingkat kepentingan (magnitude) dan signifikansi (significance) hubungan sebab akibat hipotetikal dalam seperangakat variabel.

"David Garson (2003) dari North Carolina State University mendefinisikan analisis jalur sebagai "Model perluasan regresi yang digunakan untuk menguji keselarasan matriks korelasi dengan dua atau lebih model hubungan sebab akibat yang dibandingkan oleh peneliti'. Modelnya digambarkan dalam bentuk gambar lingkaran dan panah dimana anak panah tunggal menunjukkan sebagai penyebab. Regresi dikenakan pada masingmasing variabel dalam suatu model sebagai variabel tergantung (pemberi respon) sedang yang lain sebagai penyebab. Pembobotan regresi diprediksikan dalam suatu model yang dibandingkan dengan matriks korelasi yang diobservasi untuk semua variabel dan dilakukan juga penghitungan uji keselarasan statistik.

Tujuan menggunakan analisis jalur diantaranya ialah untuk: (a) Melihat hubungan antar variabel dengan didasarkan pada model apriori; (b) Menerangkan mengapa 
variabel-variabel berkorelasi dengan menggunakan suatu model yang berurutan secara temporer; (c) Menggambar dan menguji suatu model matematis dengan menggunakan persamaan yang mendasarinya; (d) Mengidentifikasi jalur penyebab suatu variabel tertentu terhadap variabel lain yang dipengaruhinya; (e) Menghitung besarnya pengaruh satu variabel independen exogenous atau lebih terhadap variabel dependen endogenous lainnya.

Diagram jalur dapat digunakan untuk menghitung pengaruh secara langsung (direct effect) dan pengaruh tidak langsung (indirect effect) dari variabel eksogen terhadap suatu variabel endogen, pengaruh-pengaruh itu tercermin dalam apa yang disebut koefisien jalur, dimana secara matematik analisis jalur ini mengikuti model structural. (Juliansyah, 2014)

Dalam analisa jalur ini hubungan kausalitas yang menunjukkan pengaruh secara langsung dan tidak langsung antar variabel itu dapat diukur besarannya, dalam penerapannya ada beberapa asumsi yang perlu diperhatikan (Abdullah, 2015) : (a) Hubungan antar variabel haruslah linier dan aditif; (b) Semua variabel residu tidak mempunyai korelasi satu sama lain (c) Pola hubungan antar variabel adalah rekursif; (d) Skala pengukuran semua variabel minimal interval.

Persyaratan menggunakan analisis jalur : (a) Hubungan antar variabel dalam model analisis jalur harus linier; (b) Melakukan uji normalitas data, uji linieritas dan signifikansi regresi dan uji hemogenitas; (c) Melakukan uji hipotesis.

Model analisis jalur (path analysis) juga tetap menggunakan persamaan regresi, persamaan dasar dapat dituliskan sebagai berikut (Gujarati, 2003):

$$
\mathbf{Y}=\boldsymbol{\alpha}+\mathbf{X}_{1}+\mathbf{X}_{2}+\mathbf{X}_{3}+\mathbf{\varepsilon i}
$$

Kemudian, model analisis 3.1 dapat diaplikasikan berdasarkan pada diagram berikut :

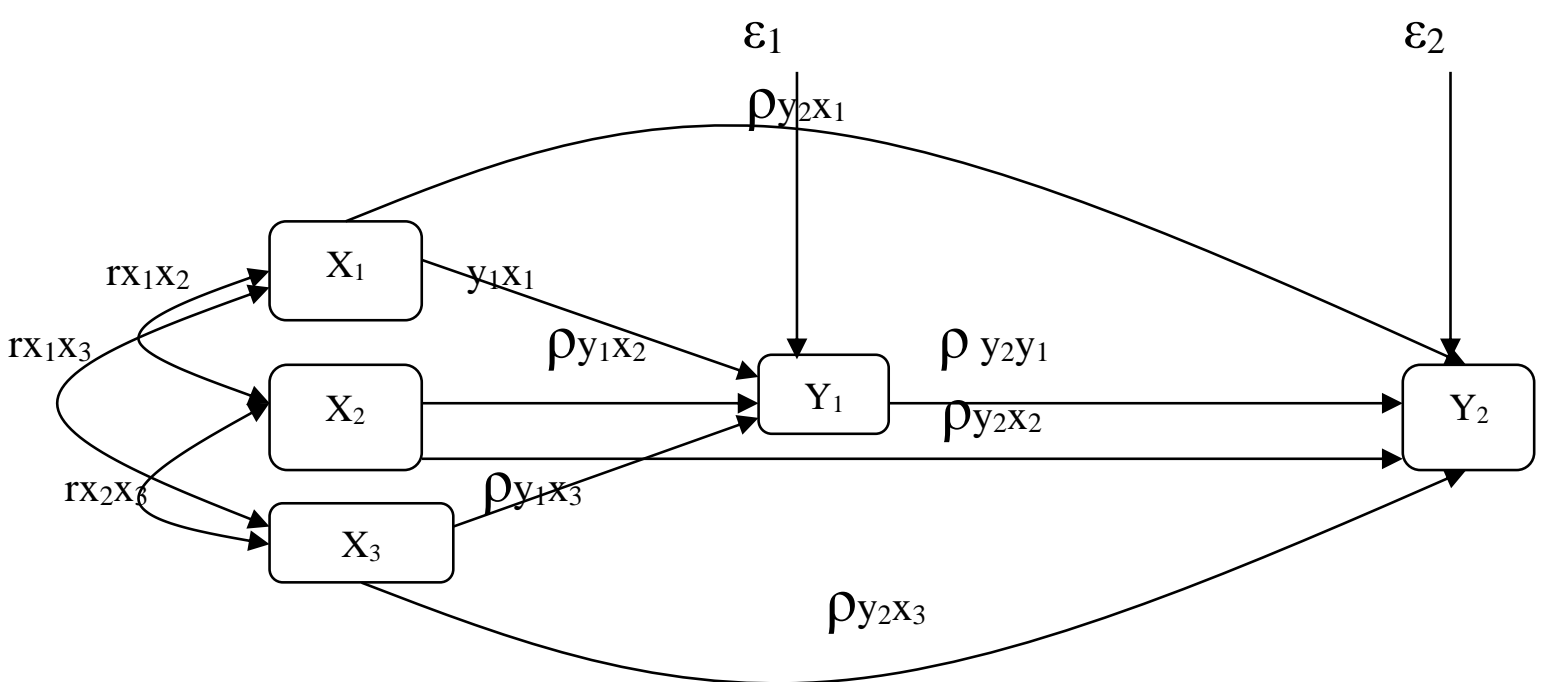

Gambar 1. Analisis jalur path

Model diagram pada gambar: 3.1. diatas menunjukkan bahwa $X_{1}, X_{2}$ dan $X_{3}$ secara bersama-sama berpengaruh secara langsung terhadap $Y_{1}$ berpengaruh terhadap $\mathrm{Y}_{2}$. Model ini menggambarkan dua struktur yang menyatakan ada dua kejadian sebab akibat yang akhirnya mengakibatkan satu kejadian yaitu $\mathrm{Y}_{2}$. Berdasarkan gambar 3.1. terdapat 2 persamaan struktural yaitu :

Pengaruh jumlah kendaraan, jumlah penduduk dan kebijakan pemerintah terhadap Penerimaan PKB di Provinsi Jambi untuk permasalahan pertama.

$$
\operatorname{LnY}_{1}=\rho_{y_{1} x_{1}} \operatorname{Ln} X_{1}+\rho_{1} x_{2} \operatorname{Ln} X_{2}+\rho_{y_{1} x_{3}} X_{3}+\rho_{y_{1}} \varepsilon_{1}
$$


Keterangan :

$\mathrm{Y}_{1}=\mathrm{Log}$ natural penerimaan pajak kendaraan bermotor

$\mathrm{X}_{1}=$ Log natural jumlah kendaraan

$\mathrm{X}_{2}=$ Log natural jumlah penduduk

$\mathrm{X}_{3}=$ Kebijakan pemerintah (variabel dummy)

$\varepsilon i_{1}=$ Koefisien pengganggu

Model analisis pengaruh variabel eksogen Jumlah Kendaraan $\left(\mathrm{X}_{1}\right)$, Jumlah Penduduk $\left(\mathrm{X}_{2}\right)$, Kebijakan Pemerintah $\left(\mathrm{X}_{3}\right)$ dan penerimaan PKB ( $\left.\mathrm{Y}_{1}\right)$ terhadap Pertumbuhan Ekonomi $\left(\mathrm{Y}_{2}\right)$ di Provinsi Jambi untuk permasalahan kedua.

$$
Y_{2}=\rho y_{1} x_{1} L n X_{1}+\rho y_{1} x_{2} \operatorname{LnX} X_{2}+\rho y_{2} x_{3} X_{3}+\rho y_{2} y_{1} L n Y_{1}+\rho y_{2} \varepsilon i_{2}
$$

Keterangan :

$\mathrm{Y}_{2} \quad=$ Pertumbuhan ekonomi

$\mathrm{LnY}_{1}=$ Log Natural penerimaan pajak kendaraan bermotor

$\mathrm{LnX}_{1}=$ Log Natural jumlah kendaraan bermotor

$\mathrm{LnX}_{2}=$ Log Natural jumlah penduduk

$\mathrm{X}_{3}=$ Kebijakan pemerintah (variabel dummy)

$\varepsilon_{2} \quad=$ Koefisien pengganggu

Model persamaan 3. diatas menunjukkan jumlah kendaraan $\left(\mathrm{X}_{1}\right)$, jumlah penduduk $\left(\mathrm{X}_{2}\right)$, kebijakan pemerintah $\left(\mathrm{X}_{3}\right)$ dan penerimaan $\mathrm{PKB}\left(\mathrm{Y}_{1}\right)$ terhadap variabel endogen Pertumbuhan Ekonomi $\left(\mathrm{Y}_{2}\right)$ dengan galat $\varepsilon_{2}$.

Setelah diperoleh koefisien regresi berganda, selanjutnya hasil koefisien variabel eksogen yang berpengaruh terhadap variabel endogen dicari hasil pengaruh secara langsung dan tidak langsungnya. Kemudian koefisien masing-masing variabel yang pengaruh secara langsung dikali koefisien variabel pengaruh secara tidak langsung. Hasilnya perkalian dijumlahkan, agar diperoleh pengaruh secara total.

\section{HASIL DAN PEMBAHASAN}

\section{Uji statistik persamaan struktural I}

Berdasarkan olahan data regresi linier berganda untuk persamaan struktural I dengan menggunakan SPPS.20 maka hasil regresi linier berganda tersebut dapat dilihat pada tabel berikut :

Tabel 1. Hasil regresi berganda persamaan struktural I

\begin{tabular}{|c|c|c|c|c|c|c|c|}
\hline \multirow[t]{2}{*}{ Model } & \multicolumn{2}{|c|}{$\begin{array}{l}\text { Unstandardized } \\
\text { Coefficients }\end{array}$} & \multirow{2}{*}{$\begin{array}{c}\begin{array}{c}\text { Standardized } \\
\text { Coefficients }\end{array} \\
\text { Beta }\end{array}$} & \multirow[t]{2}{*}{$\mathbf{t}$} & \multirow[t]{2}{*}{ Sig. } & \multicolumn{2}{|c|}{$\begin{array}{l}\text { Collinearity } \\
\text { Statistics }\end{array}$} \\
\hline & $\mathbf{B}$ & Std. Error & & & & Tolerance & VIF \\
\hline 1 (Constant) & $-56,394$ & 14,028 & & $-4,020$ & ,001 & & \\
\hline $\mathrm{X} 1$ & ,117 & , 160 & 147 & ,727 & , 478 & ,046 & 21,737 \\
\hline $\mathrm{X} 2$ & 4,483 & 1,083 & 839 & 4,140 & ,001 & ,046 & 21,933 \\
\hline X3 & 023 & 066 & 016 & 356 & ,727 & 946 & 1,057 \\
\hline
\end{tabular}

a. Dependent Variable: Y1

Sumner: Data diolah, 2020

Berdasarkan hasil regresi terdapat variabel bebas yang tidak berpengaruh signifikan terhadap penerimaan pajak kendaraan bermotor maka model persamaan struktural I perlu 
diperbaiki melalui model Trimming. Proposisi jumlah penduduk mempunyai pengaruh yang signifikan terhadap penerimaan pajak kendaraan bermotor.

Berdasarkan olahan data regresi sederhana untuk persamaan struktural I setelah menggunakan model Trimming dengan menggunakan SPPS.20 maka hasil regresi linier sederhana tersebut dapat dilihat pada tabel berikut :

Tabel 2. Hasil regresi sedehana persamaan struktural i setelah trimming

\begin{tabular}{|c|c|c|c|c|c|c|c|}
\hline \multirow[t]{2}{*}{ Model } & \multicolumn{2}{|c|}{$\begin{array}{l}\text { Unstandardized } \\
\text { Coefficients }\end{array}$} & \multirow{2}{*}{$\begin{array}{c}\begin{array}{c}\text { Standardized } \\
\text { Coefficients }\end{array} \\
\text { Beta } \\
\end{array}$} & \multirow[t]{2}{*}{$\mathbf{t}$} & \multirow[t]{2}{*}{ Sig. } & \multicolumn{2}{|c|}{$\begin{array}{c}\text { Collinearity } \\
\text { Statistics }\end{array}$} \\
\hline & B & Std. Error & & & & Tolerance & VIF \\
\hline 1 (Constant) & $-66,497$ & 3,301 & & 20,143 & ,000 & & \\
\hline $\mathrm{X} 2$ & 5,267 & ,222 & ,985 & 23,766 & ,000 & 1,000 & 1,000 \\
\hline
\end{tabular}

a. Dependent Variable: Y1

Sumber: Data diolah, 2020

Dari hasil pengujian diperoleh nilai probabilita untuk variabel jumlah penduduk sebesar 0,000 . dengan tingkat keyakinan $(\alpha=5 \%)$, dari perhitungan tersebut dapat dilihat bahwa nilai probabilita lebih kecil dari alpha $(0,000<0,05)$, artinya Ho ditolak dan Ha diterima artinya jumlah penduduk berpengaruh signifikan terhadap penerimaan pajak kendaraan bermotor Provinsi Jambi.

Selanjutnya untuk mengetahui nilai koefisien jalur variabel bebas dapat dilihat pada tabel 5.2 pada nilai coefficient beta. Nilai koefisien variabel nilai koefisien variabel jumlah penduduk yaitu 0,985 , sementara nilai residu yaitu 0,029

sehingga diperoleh diagram jalur yang dapat digambarkan pada gambar 5.1 berikut:

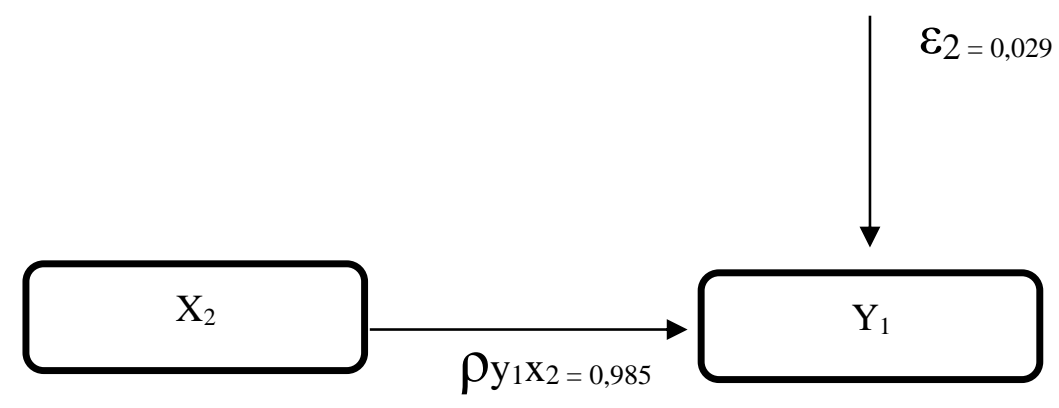

Gambar 3. Diagram jalur persamaan struktural I setelah trimming

Pengaruh langsung dari variabel eksogen yaitu jumlah penduduk terhadap penerimaan pajak kendaraan bermotor dapat terlihat pada tabel 5.3 berikut :

Tabel 3. Pengaruh lansung dan pengaruh total persamaan struktural $I$ variabel $X_{2}$ terhadap $\mathrm{Y}_{1}$

\begin{tabular}{|c|c|c|c|c|}
\hline \multirow{3}{*}{$\begin{array}{c}\text { Pengaruh } \\
\text { Variabel }\end{array}$} & \multicolumn{3}{|c|}{ Pengaruh Kausal } & \multirow{3}{*}{$\begin{array}{c}\text { Pengaruh } \\
\text { Total } \\
(\%)\end{array}$} \\
\hline & \multirow{2}{*}{ Langsung (\%) } & \multicolumn{2}{|c|}{ Tidak Langsung } & \\
\hline & & $\mathrm{X}_{1}(\%)$ & $\mathbf{X}_{2}(\%)$ & \\
\hline $\mathrm{X}_{2} \rightarrow \mathrm{Y}_{1}$ & 97,1 & - & - & 97,1 \\
\hline \multicolumn{4}{|c|}{ Pengaruh variabel $\mathrm{X}_{2}$ terhadap $\mathrm{Y}_{1}=\mathrm{R}^{2}$} & 97,1 \\
\hline \multicolumn{4}{|c|}{ Pengaruh variabel luar } & 2,9 \\
\hline \multicolumn{4}{|c|}{ Total } & $\mathbf{1 0 0 , 0}$ \\
\hline
\end{tabular}

Sumber: Data diolah, 2020 
Atas dasar perhitungan di atas, dapat dikemukakan hal-hal yaitu kekuatan jumlah penduduk yang secara langsung menentukan perubahan-perubahan penerimaan pajak kendaraan bermotor sebesar 97,1 persen.

Pengaruh jumlah kendaraan bermotor, jumlah penduduk, kebijakan pemerintah dan penerimaan PKB terhadap pertumbuhan ekonomi di Provinsi Jambi

Berdasarkan olahan data regresi linier berganda untuk persamaan struktural II dengan menggunakan SPPS.20 maka hasil regresi linier berganda tersebut dapat dilihat pada tabel berikut :

Tabel 4. Hasil regresi berganda persamaan struktural II

\begin{tabular}{|c|c|c|c|c|c|c|c|c|}
\hline \multirow{2}{*}{\multicolumn{2}{|c|}{ Model }} & \multicolumn{2}{|c|}{$\begin{array}{c}\text { Unstandardized } \\
\text { Coefficients }\end{array}$} & \multirow{2}{*}{$\begin{array}{c}\begin{array}{c}\text { Standardized } \\
\text { Coefficients }\end{array} \\
\text { Beta } \\
\end{array}$} & \multirow[t]{2}{*}{$t$} & \multirow{2}{*}{ Sig. } & \multicolumn{2}{|c|}{ Collinearity Statistics } \\
\hline & & B & Std. Error & & & & Tolerance & VIF \\
\hline 1 & (Constant) & 554,941 & 158,722 & & 3,496 & ,004 & & \\
\hline & $\mathrm{X} 1$ & 4,382 & 1,281 & 2,883 & 3,420 & ,004 & 044 & 22,503 \\
\hline & $\mathrm{X} 2$ & $-43,311$ & 12,441 & $-4,241$ & $-3,481$ & ,004 & ,021 & 46,998 \\
\hline & X3 & ,065 & ,519 & ,023 & ,126 & ,902 & ,938 & 1,066 \\
\hline & Y1 & 3,116 & 2,027 & 1,631 & 1,538 & ,146 & ,028 & 35,641 \\
\hline
\end{tabular}

a. Dependent Variable: Y2

Sumber: Data diolah, 2020

Berdasarkan hasil regresi terdapat variabel bebas yang tidak berpengaruh signifikan terhadap pertumbuhan ekonomi maka model persamaan struktural II perlu diperbaiki melalui model Trimming. Proposisi menjadi jumlah kendaraan bermotor dan jumlah penduduk mempunyai pengaruh yang signifikan terhadap pertumbuhan ekonomi.

Berdasarkan olahan data regresi linier berganda untuk persamaan struktural I setelah menggunakan model Trimming dengan menggunakan SPPS.20 maka hasil regresi linier berganda tersebut dapat dilihat pada tabel berikut :

Tabel 5. Hasil regresi berganda persamaan struktural ii setelah trimming

\begin{tabular}{|c|c|c|c|c|c|c|c|}
\hline \multirow[t]{2}{*}{ Model } & \multicolumn{2}{|c|}{$\begin{array}{l}\text { Unstandardized } \\
\text { Coefficients }\end{array}$} & \multirow{2}{*}{$\begin{array}{c}\begin{array}{c}\text { Standardized } \\
\text { Coefficients }\end{array} \\
\text { Beta }\end{array}$} & \multirow[t]{2}{*}{$\mathbf{t}$} & \multirow[t]{2}{*}{ Sig. } & \multicolumn{2}{|c|}{$\begin{array}{c}\text { Collinearity } \\
\text { Statistics }\end{array}$} \\
\hline & B & Std. Error & & & & Tolerance & VIF \\
\hline 1 (Constant) & 375,556 & 110,757 & & 3,391 & ,004 & & \\
\hline $\mathrm{X} 1$ & 4,722 & 1,273 & 3,106 & 3,709 & 002 & , 117 & 8,571 \\
\hline $\mathrm{X} 2$ & $-29,072$ & 8,554 & $-2,846$ & $-3,399$ & ,004 & , 117 & 8,571 \\
\hline
\end{tabular}

a. Dependent Variable: Y2

Sumber: Data diolah, 2020

Nilai untuk koefisien jumlah kendaraan bermotor adalah 3,106, hal ini menunjukkan adanya pengaruh positif antara variabel jumlah kendaraan bermotor terhadap pertumbuhan ekonomi. Artinya, bila terjadi kenaikan jumlah kendaraan bermotor sebesar 1 persen maka akan meningkatkan pertumbuhan ekonomi sebesar 3,106 persen.

Selanjutnya nilai untuk jumlah penduduk adalah -2,846, angka ini menunjukkan adanya pengaruh negatif antara jumlah penduduk terhadap pertumbuhan ekonomi. Artinya, bila terjadi kenaikan jumlah penduduk sebesar 1 persen maka akan menurunkan pertumbuhan ekonomi sebesar 2,846 persen. 
Selanjutnya untuk mengetahui nilai koefisien jalur variabel bebas dapat dilihat pada Tabel 6. pada nilai coefficient beta. Nilai koefisien variabel jumlah kendaraan bermotor yaitu 3,106, dan nilai koefisien variabel jumlah penduduk yaitu -2,846, sementara nilai residu yaitu 0,526 . Untuk mengetahui nilai koefisien jalur $\mathrm{rx}_{1} \mathrm{x}_{2}$ dapat dilihat pada tabel korelasi berikut :

Tabel 6. Hasil korelasi persamaan struktural i setelah trimming

\begin{tabular}{llrr}
\hline & X1 & \multicolumn{1}{c}{ X2 } \\
\hline X1 & Pearson Correlation & 1 &, $977^{* *}$ \\
& Sig. (2-tailed) & &, 000 \\
N & 19 & 18 \\
\hline
\end{tabular}

Sumber: Data diolah, 2020

Berdasarkan hasil korelasi dapat dilihat pearson correlation antara jumlah kendaraan bermotor dengan jumlah kendaraan nilai korelasinya sebesar 0,977 sehingga diperoleh diagram jalur yang dapat digambarkan pada gambar 5.5 berikut:

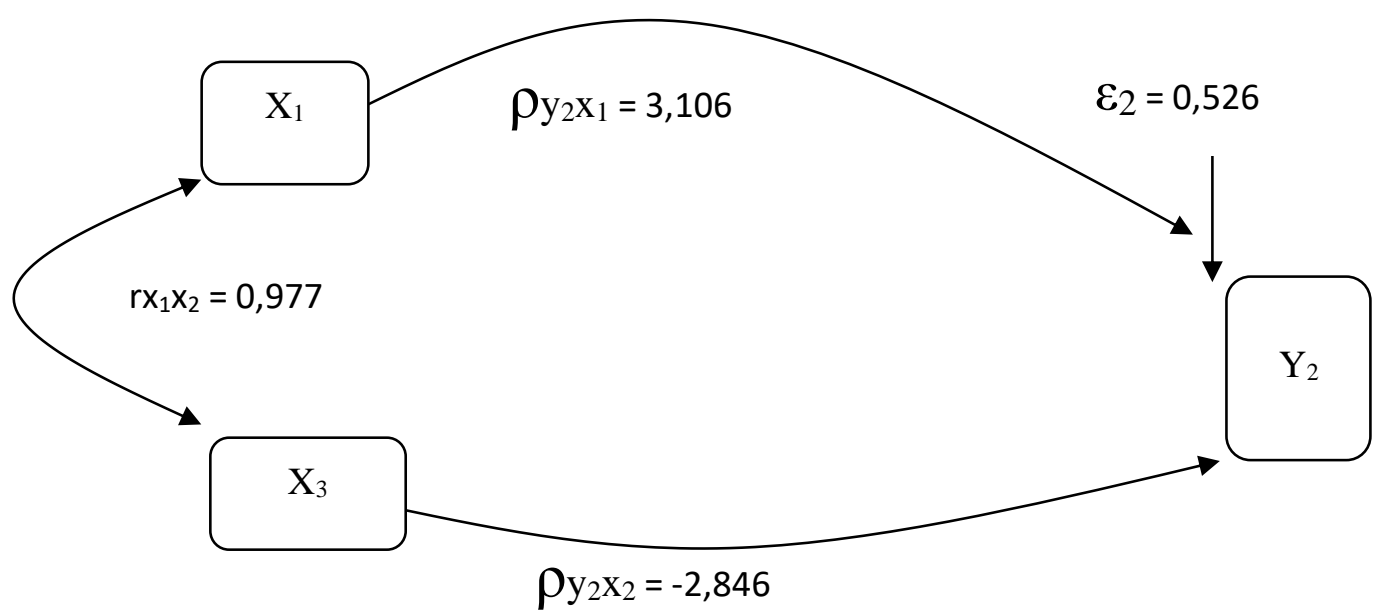

Gambar 4. Diagram jalur persamaan struktural II

Pengaruh langsung dan pengaruh tidak langsung dari variabel eksogen yaitu jumlah kendaraan bermotor dan jumlah penduduk terhadap pertumbuhan ekonomi dapat terlihat pada tabel 5.10 berikut :

Tabel 7. Pengaruh lansung, pengaruh tidak lansung dan pengaruh total persamaan struktural II variabel $\mathrm{X}_{1}$ dan $\mathrm{X}_{2}$ terhadap $\mathrm{Y}_{2}$

\begin{tabular}{|c|c|c|c|c|}
\hline \multirow{3}{*}{$\begin{array}{c}\text { Pengaruh } \\
\text { variabel }\end{array}$} & \multicolumn{3}{|c|}{ Pengaruh kausal } & \multirow{3}{*}{ Pengaruh total $(\%)$} \\
\hline & \multirow{2}{*}{$\begin{array}{c}\text { Langsung } \\
(\%)\end{array}$} & \multicolumn{2}{|c|}{ Tidak langsung $(\%)$} & \\
\hline & & $\mathrm{X}_{1}(\%)$ & $\mathbf{X}_{2}(\%)$ & \\
\hline $\mathrm{X}_{1} \rightarrow \mathrm{Y}_{2}$ & 964,72 & - & $-863,63$ & 101,09 \\
\hline $\mathrm{X}_{2} \rightarrow \mathrm{Y}_{2}$ & 809,97 & $-863,63$ & - & $-53,66$ \\
\hline \multicolumn{4}{|c|}{ Pengaruh variabel $\mathrm{X}_{1}$ dan $\mathrm{X}_{2}$ terhadap $\mathrm{Y}_{2}=\mathrm{R}^{2}$} & 47,43 \\
\hline \multicolumn{4}{|c|}{ Pengaruh variabel luar } & 52,57 \\
\hline \multicolumn{4}{|l|}{ Total } & $\mathbf{1 0 0 , 0}$ \\
\hline
\end{tabular}

Sumber: Data diolah, 2020 
Kekuatan jumlah kendaraan bermotor yang secara langsung menentukan perubahan-perubahan pertumbuhan ekonomi sebesar 964,7 persen, dan yang melalui hubungannya dengan jumlah penduduk sebesar $-863,6$ persen. secara total jumlah kendaraan bermotor menentukan perubahan-perubahan pertumbuhan ekonomi sebesar 101,09 persen. Kekuatan jumlah penduduk yang secara langsung menentukan perubahanperubahan pertumbuhan ekonomi sebesar 809,97 persen, dan yang melalui hubungannya dengan jumlah kendaraan bermotor sebesar $-863,63$ persen. secara total jumlah penduduk menentukan perubahan-perubahan pertumbuhan ekonomi sebesar -53,66 persen.

Setelah ditemukan koefisien jalur pada variabel bebas yang mempunyai pengaruh terhadap variabel maka dapat dibentuk skema path analysis (analisis jalur) dengan cara penggabungan dua hasil persamaan struktural tersebut.

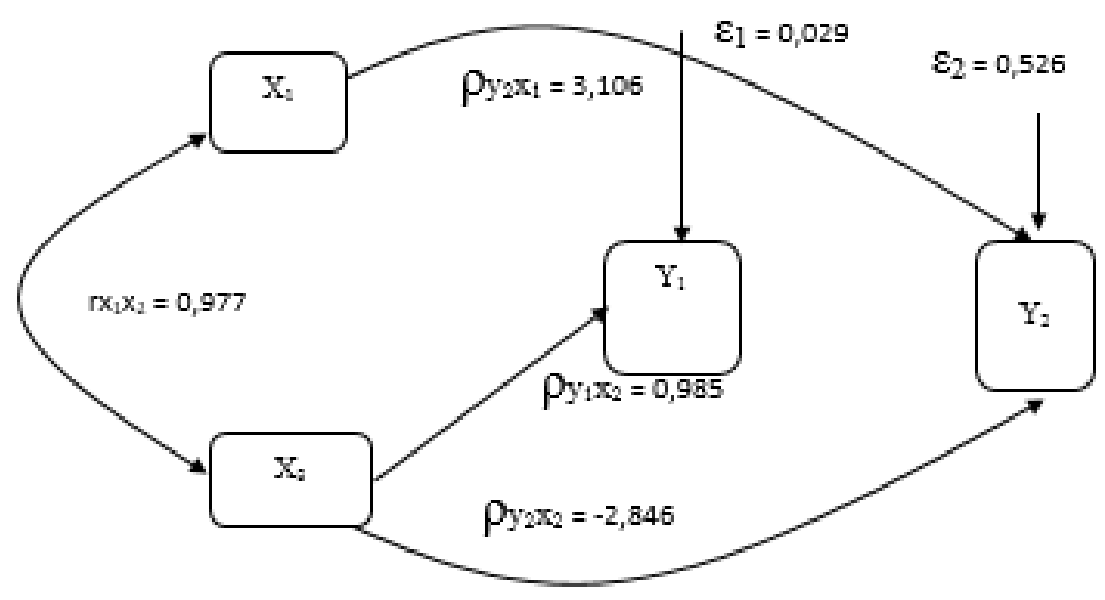

Gambar 5. Diagram jalur persamaan struktural I dan persamaan struktural II

Berdasarkan Gambar 4. diketahui bahwa kontribusi jumlah penduduk di Provinsi Jambi secara langsung berdampak positif terhadap penerimaan pajak kendaraan bermotor sebesar 97,1 persen. Hasil ini menunjukkan bahwa jumlah penduduk lebih besar pengaruhnya terhadap penerimaan pajak kendaraan bermotor. Selaras dengan hasil tyersebut bahwa untuk meningkatkan penerimaan pajak kendaraan bermotor pemerintah seharusnya dapat mengoptimalkan potensi pajak kendaraan bermotor tersebut kepada penduduk yang memiliki wajib pajak membayar kendaraan.

Berdasarkan Tabel 5. diketahui bahwa kontribusi jumlah kendaraan bermotor yang secara langsung berdampak positif terhadap pertumbuhan ekonomi sebesar 964,7 persen. Selanjutnya pengaruh tidak langsung jumlah kendaraan bermotor melalui jumlah penduduk berkontribusi negatif terhadap pertumbuhan ekonomi di Provinsi Jambi yaitu sebesar $-863,6$ persen. sehingga didapatkan total kontribusinya yaitu sebesar 101,09 persen. Hasil ini menunjukkan bahwa pengaruh langsung jumlah kendaraan bermotor terhadap pertumbuhan ekonomi lebih baik untuk dijadikan sebuah kebijakan peningkatan pertumbuhan ekonomi dibandingan dengan pengaruh tidak langsung melalui jumlah penduduk.

Kontribusi jumlah penduduk di Provinsi Jambi secara langsung berdampak positif terhadap pertumbuhan ekonomi sebesar 809,97 persen. Selanjutnya pengaruh tidak langsung jumlah penduduk melalui jumlah kendaraan bermotor berkontribusi negatif terhadap pertumbuhan ekonomi di Provinsi Jambi yaitu sebesar 863,63 persen, sehingga 
didapatkan total kontribusinya yaitu sebesar $-53,66$ persen. Hasil ini sama dengan variabel jumlah kendaraan beromotor yang menunjukkan bahwa pengaruh langsung jumlah penduduk terhadap pertumbuhan ekonomi lebih baik untuk dijadikan sebuah kebijakan peningkatan pertumbuhan ekonomi dibandingan dengan pengaruh tidak langsung melalui jumlah kendaraan bermotor.

\section{KESIMPULAN DAN SARAN}

\section{Kesimpulan}

Perkembangan jumlah kendaraan bermotor, jumlah penduduk, penerimaan pajak kendaraan bermotor dan pertumbuhan ekonomi mengalami fluktuasi selama tahun 2000 sampai tahun 2018. Sedangkan kebijakan pemerintah terhadap penghapusan sanksi pajak kendaraan beromotr hanya terjadi 6 kali selama 19 tahun penelitian. Hasil persamaan struktural I yaitu variabel bebas yang mempengaruhi penerimaan pajak kendaraan bermotor adalah jumlah penduduk. Hasil path analisis untuk persamaan struktural I yaitu kontribusi jumlah penduduk di Provinsi Jambi secara langsung berdampak positif terhadap penerimaan pajak kendaraan bermotor di Provinsi Jambi. Hasil persamaan struktural II yaitu variabel bebas yang mempengaruhi pertumbuhan ekonomi adalah jumlah kendaraan dan jumlah penduduk. Hasil path analisis untuk persamaan struktural II yaitu kontribusi jumlah kendaraan bermotor di Provinsi Jambi secara langsung berdampak positif dan pengaruh tidak langsung melalui jumlah penduduk berkontribusi negatif terhadap pertumbuhan ekonomi di Provinsi Jambi. Selanjutnya kontribusi jumlah penduduk di Provinsi Jambi secara langsung berdampak positif dan pengaruh tidak langsung melalui jumlah kendaraan bermotor berkontribusi negatif terhadap pertumbuhan ekonomi di Provinsi Jambi.

\section{Saran}

Dampak jumlah kendaraan bermotor, jumlah penduduk dan kebijakan pemerintah terhadap penerimaan pajak kendaraan bermotor serta pertumbuhan ekonomi, menunjukkan hasil yang berbeda untuk berbagai penelitian. Untuk mendapatkan hasil yang lebih komprehensif, penelitian sebaiknya mencakup rentang waktu sekitar 20 atau 30 tahun. Oleh karenanya, penulis menyarankan bagi yang tertarik dengan kajian ini, untuk menggunakan rentang waktu yang lebih panjang. Kemudian memasukkan variabelvariabel lain yang mempunyai teori keterkaitan terhadap variabel penerimaan pajak kendaraan bermotor dan pertumbuhan ekonomi, sehingga cakupan penelitian lebih luas dan dalam melakukan uji asumsi hipotesis lebih signifikan. Pemerintah Provinsi Jambi seharusnya dapat meningkatkan penerimaan pajak kendaraan bermotor dengan mengoptimalkan potensi pajak yang terus meningkat setiap tahunnya. Potensi yang dimaksud adalah jumlah penduduk yang meningkat setiap tahunnya. Kedua variabel tersebut menjadi objek dan wajib pajak yang menjadi sasaran pajak. Cara mengoptimalkan pajak tersebut dengan terus bekerja sama dengan pihak polisi lalu lintas untuk melakukan razia terhadap pemilik kendaran bermotor serta menghimbau kepada pemilik kendaraan bermotor untuk tetap patuh terhadap pembayaran pajak kendaraan bermotor. Pemerintah Provinsi Jambi dapat mendongkrak laju pertumbuhan ekonominya dengan meningkatkan jumlah kendaraan bermotor di Provinsi Jambi. Peningkatan jumlah kendaraan bermotor tersebut akan mempengaruhi sektor perdagangan besar dan eceran; reparasi mobil dan sepeda motor secara positif. 


\section{DAFTAR PUSTAKA}

David, Garson.(2003). Aplikasi Amos. PT Gramedia Utama: Jakarta.

Gujarati, Damodar.(2006). Dasar-dasar ekonometrika. Erlangga: Jakarta

J Junaidi, Y Yulmardi, H Hardiani. (2020).Jambi City community transportation modes and influencing factors, Jurnal Perspektif Pembiayaan dan Pembangunan Daerah, 8 (5), 455-464

Kaho, Josef Riwu. (2007). Prospek otonomi daerah. PT Raja Grafindo Persada: Jakarta

Noor, Juliansyah. (2014). Metodologi penelitian. Kencana Prenada Media Group: Jakarta

RIA Aditya, Z Zulfanetti, H Heriberta. (2021).Evaluasi penerimaan pajak kendaraan bermotor (PKB) dan bea balik nama kendaraan bermotor (BBN-KB) serta dampaknya terhadap pendapatan asli daerah di Provinsi Jambi, Jurnal Paradigma Ekonomika, 16 (1), 151-166

Robert, D. Retherford. (1993). Statistical models for casual analisysis. USA. https://onlinelibrary.wiley.com/doi/10.1002/9781118033135.ch3/summary

Streiner, David L. (2005). Finding our way: an introduction to path analysis. Can J Psychiatry, 50(2).

Webley, Paul dan Stephan Lea. (1997). Path analysis. exter, Department of Psychology, University of Exeter: UK. 